FACTA UNIVERSITATIS

Series: Economics and Organization Vol. 15, N $\mathrm{N}^{\mathrm{o}} 3,2018$, pp. 189 - 201

https://doi.org/10.22190/FUEO1803189S

Original Scientific Paper

\title{
KNOWLEDGE MANAGEMENT: \\ EVIDENCE FROM SERBIAN BANKING SECTOR
}

UDC 005.94:336.71(497.11)

\section{Vesna Stojanović-Aleksić, Jelena Erić-Nielsen, Aleksandra Bošković}

\author{
University of Kragujevac, Faculty of Economics, Serbia
}

\begin{abstract}
Knowledge management is necessary in order to face the contemporary challenges in banking industry, related to hyper-competition, market differentiation and improvement of business performance. It involves several phases, and the paper focuses on the knowledge creation and knowledge sharing. Also, a brief insight into the features of an organizational culture that supports knowledge management is provided. The goals of the research are to determine the levels of knowledge creation, knowledge sharing and knowledge-supporting organizational culture, in the Serbian banking sector. After the literature review, a survey was conducted and data was processed with a statistical method. The paper contributes to the literature both in the fields of banking management and knowledge management. The findings may be useful to bank managers, because the importance of knowledge management in banks is highlighted and practical guidelines for the improvement of less developed aspects of knowledge creation and sharing are provided.
\end{abstract}

Key words: knowledge management, knowledge creation, knowledge sharing, banking management

JEL Classification: M21, D83, M14, G21, G41

\section{INTRODUCTION}

Due to the highly competitive environment and the constant tendency towards maintaining and improving profitability and liquidity, financial institutions are faced with ongoing challenges, such as an urge to provide services more efficiently and manage risks involving complex and intangible elements. Dugalic (2016) identified a number of factors that will significantly shape the banks of the future, and some of them are: "the rise of

Received June 12, 2018 / Accepted July 09, 2018

Corresponding author: Aleksandra Bošković

University of Kragujevac, Faculty of Economics, Đure Pucara Starog 3, 34000 Kragujevac, Serbia

E-mail: aboskovic@kg.ac.rs 
new markets, population growth in developing countries, an increasing average age of the population, urbanization, new energy sources, modern technology, etc."

All of these factors influence the need to make adjustments in order to meet the new market conditions. Whether the bank's competitive strategy is based on a cost leadership, market differentiation or focusing on a specific market segment, it is necessary to permanently explore and implement new ways to achieve specific goals. The precondition for solving complex problems is the successful management of knowledge. It is necessary to adapt the organizational design and culture of modern banks to the knowledge management requirements, in order to develop the new ways of providing services and to improve various processes at each organizational level. Knowledge management $(\mathrm{KM})$ is a system of managerial activities related to the creation, accumulation, sharing or transfer, use and internalization of knowledge (Lee et al., 2005). The paper emphasizes the phases of knowledge creation and sharing, as important preconditions for all further activities in knowledge management.

We discuss the process of knowledge management in the specific context of the Serbian banking sector. Based on the insight into the latest available Financial Position and Financial Performance Report of the Banking Sector in the Republic of Serbia, it can be concluded that, although there has been a slight growth of financial indicators in recent years, this sector continues to operate in a high business risk area and is exposed to numerous pressures from the domestic and external environment (Association of Serbian Banks, 2016). Many of the issues are related to the problems that permeate the entire domestic economy, as well as the process of legal system reform, which is still in progress. The banks are trying to maintain their stability through different possibilities from regular operations, as well as from the processes of recapitalization, mergers and acquisitions. For all these activities, knowledge and information management is very important, both within the banks themselves, and between potential partners, competitors, and all other stakeholders.

The implementation of the knowledge management still faces numerous challenges, even in more developed economies, so there is an increase in the volume of research that examine KM development and various individual, organizational, technological, cultural and other factors affecting it (e.g. Islam et al., 2015; Mahmoudsalehi et al., 2012; Gupta \& Govindarajan, 2000; Curado, 2008; Jayasundara, 2008; Nonaka \& Takeuchi, 1995; Nonaka, 1994: Davies et al., 1995). Hence, there is still a lot of space for knowledge management improvement in companies operating in Serbia, too. The research is motivated by a tendency to contribute to domestic and foreign literature from the problem area covered, as well as to provide relevant information to banking management, in order to guide future decisions and activities more successfully.

The main goals of the research are to determine the levels of development of the knowledge creation, knowledge sharing and organizational culture that supports knowledge in the banking sector in Serbia. Also, we strive to find out whether the hierarchical level influences the processes of creating and sharing knowledge, and to formulate specificproposals and practical guidelines for improving knowledge management and knowledge culture in banks. After the literature review, the quantitative methodology was applied. The survey method was applied, and the results were analyzed using adequate statistical techniques. 


\section{THE CONCEPT OF KNOWLEDGE MANAGEMENT}

Unlike the traditional resource-based perspective of an enterprise, the knowledge based view of an organization has taken the growing importance in modern strategic management, and the concept of knowledge management is especially pointed out. In fact, knowledge is a critical resource for almost all modern organizations, regardless of activity, size, age, which affects their sustainable competitive advantage. The knowledge management process consists of numerous sub-processes, which different authors classify in different ways. Generally speaking, the most striking differences are between creating knowledge, sharing knowledge, and using or applying knowledge.

Knowledge creation is the first phase in the knowledge management process and it is a very complex process itself, which is difficult to conceptualize, operationalize and measure. It was introduced by Nonaka et al. (1994, 2000), who developed one of the earliest theories of knowledge creation, based on three elements (SECI model, Ba, and knowledge assets). Knowledge sharing or transfer is the exchange of information between the two parties, the source, who owns and shares knowledge and the recipient, who receives or acquires knowledge (Cavaliere et al., 2015; Ma et al., 2014; Tangaraja et al., 2015). These parties are individuals and groups within the organization, but knowledge sharing can also take place among actors formally belonging to different organizations, which is especially pronounced in organizational networks and flexible organizational systems with fluid borders.

Although, theoretically, there is a distinction between the process of creating, sharing and using knowledge, as well as many other related processes and subprocesses, in practice these activities are usually carried out simultaneously and there are many interdependencies among them (Slavković, 2013). Essentially, the use of knowledge refers to the establishment of systems and processes that enable all other phases and subphases within the organization's knowledge management process.

\section{THE IMPORTANCE OF KNOWLEDGE MANAGEMENT IN BANKING SECTOR}

Banks around the world are faced with rising competition and a constant pressure to improve their market performance. In the last decades, their customers are much more demanding and it is increasingly difficult to build and maintain loyalty. Also, customers have the tendency to use the services of more than one bank and/or financial institution and to make frequent changes in their funding sources in order to achieve short-term benefits (Davies et al., 1995), which is particularly expressed in the retail banking. On the other hand, there are constant problems of small and medium-sized enterprises (SMEs) related to finding sources of funding. This problem is especially pronounced in Serbia where a large number of companies continue to operate in the high risk zone (Association of Serbian Banks, 2016, p. 10), which also increases the credit risk for banks. However, in addition to its real component, the risk in the B2B market can be caused by an informational asymmetry between enterprises and banks (Della Peruta et al., 2014; Hutchinson \& Xavier, 2006), which increases the risk for banks when doing business on the B2B market. This is a risk component that can be minimized by adequate knowledge management.

Market differentiation is particularly difficult in the banking sector, bearing in mind the generic character of financial services. In addition, it is very important to maintain the good relations with many stakeholders. This requires the establishment of a balance 
between different, often conflicting goals and requirements. Consequently, the banks must continuously focus on improving the efficiency and quality of each segment of the business process, and still generating innovations where it is possible.

A variety of data and information from the internal and external environment must be received and correctly interpreted in a short time, which is why it is very important to develop knowledge creation process, as a sub-phase of the knowledge management process. The knowledge can be created inside of an organization or in interaction with the external actors. Some of the important preconditions for successful knowledge creation are related to the use of electronic bulletin boards, the awareness of what information is needed for the performance of tasks, gradually bringing employees into new tasks, i.e. training employees to work on new procedures and applications, brainstorming, using different knowledge sources provided by the organization (Lee et al., 2005). In addition, management should value the new ideas coming from employees, encourage them to connect with experts outside the organization and motivate them to actively improve their competencies.

Bearing in mind the high interdependence of activities and tasks in banking, both at the same hierarchical level and between different levels and organizational units, knowledge sharing is a prerequisite for efficient and quality service delivery, risks minimization, reduction of errors and increase in customer satisfaction and loyalty, as an ultimate goal of the modern banks. It is equally important to create and share knowledge within an organization, on the one hand, and to exchange the information with the external stakeholders, such as clients, experts, regulators, media and other actors, on the other hand. According to Della Peruta et al. (2014) knowledge sharing is very important in cooperation between banks and small and mediumsized enterprises. Namely, the access to funding sources can be improved through cooperation, in particular by supporting the relationship between SMEs and the banking system, which leads to converting complex risks into the simpler ones.

Facing all these requirements in the banking sector must be supported by an adequate knowledge management system, based on advanced IC technology (Mirzaee \& Ghaffari, 2018). Within the process of technology development, the Big Data softwares have emerged, that enable handling of large amounts of data that traditional applications cannot process in an adequate way. Organizations use big databases, which often include unstructured data, such as, for example, data from mobile phones, GPS maps, video surveillance cameras, etc. (Aleksić-Mirić, 2017), that are available in real time. In Big Data analytics, knowledge management plays a central role. On the one hand, knowledge management in modern organizations is not possible without the analysis of a Big Data, and on the other hand, human knowledge is up to the development of technology and people are the ones who decide how to use information generated from large databases (Pauleen \& Wang, 2017). Some of the specific support systems for knowledge management, which are often used in banks, include information support systems for risk management, Decision Support Systems, Data Warehouse and Data Mining (Jayasundara, 2008). Most of the banks have implemented modern IT solutions, and science and practice are still searching for new ways to digitize banking operations. The specific challenges are related to attracting and educating customers regarding the use of electronic and mobile banking, where it is important to ensure a high quality knowledge transfer process between the bank and its customers.

In addition to the technology, there are various individual, organizational and other factors that influence the knowledge creation and sharing in general, and also in the 
banking sector. However, the paper focuses on organizational culture as a factor of knowledge creation and sharing, bearing in mind the importance of the culture for the performance of financial organizations (Al-Abdullat \& Dababneh, 2018; Faisal et al., 2013). Knowledge supporting culture, also known as the knowledge culture, is one of the most important conditions that ensure the effective and efficient movement of knowledge through the organization (Islam et al., 2015). Some of the most significant characteristics of the organizational culture that supports knowledge are: an accessible relationship of colleagues, a willingness to help others, but also to seek help, awareness and understanding of the importance of knowledge for the success of the company, encouraging employees to research and experiment, evaluating individual performance based on knowledge and expertise, motivation to discuss business, senior management support in terms of creating, sharing and applying knowledge.

\section{Knowledge Creation and Knowledge Sharing in Serbian Banking Sector: RESULTS OF THE RESEARCH}

Starting from the research goals, a short survey was conducted on the sample of banks operating on the territory of the Republic of Serbia. Out of 31 banks in Serbia (National Bank of Serbia, 2018), a sample of 11 banks was selected based on the random sampling procedure. Bank managers were contacted and asked in person to distribute questionnaires to different employees (in terms of their organizational role) throughout the company, by their own random selection. This decision was motivated by the tendency to get as diverse responses as possible, since the processes of knowledge creation and sharing may differ between organizational units, roles and hierarchical positions. In consultation with managers, the authors decided to send five questionnaires per company. The respondents were informed that the survey is completely anonymous, voluntary based and that the results will be used only for the scientific research purposes. Out of the 55 distributed, we received 40 filled-in and usable questionnaires, so the response rate is $72.7 \%$, which is a high percentage. The structure of the sample is shown in Table 1.

Table 1 Structure of respondents according to demographic characteristics

\begin{tabular}{llrr}
\hline & & $\mathrm{n}$ & $\%$ \\
\hline Gender & Male & 16 & $40.0 \%$ \\
Education & Femaele & 24 & $60.0 \%$ \\
& High school & 5 & $12.5 \%$ \\
& College & 6 & $15.0 \%$ \\
& University (BSc) & 24 & $60.0 \%$ \\
Hierarchy & MSc/Phd & 5 & $12.5 \%$ \\
& Employee & 14 & $35.0 \%$ \\
Age & Manager & 26 & $65.0 \%$ \\
& $<25$ & 2 & $5.0 \%$ \\
& $26-35$ & 13 & $32.5 \%$ \\
& $36-45$ & 14 & $35.0 \%$ \\
& $46-55$ & 6 & $15.0 \%$ \\
Total & $>55$ & 5 & $12.5 \%$ \\
\hline & & 40 & $100 \%$ \\
\hline
\end{tabular}

Source: Authors 
The questionnaire is composed of four parts and includes a total of 20 questions. The development of the questionnaire is based on the literature review, but the final structure of the questionnaire is the result of the original scientific approach of the co-authors. First, a focus group was formed consisting of co-authors of this paper and a few other university professors who discussed the existing scales and decided what items should be included in the questionnaire in accordance with the purpose and goals of research, and how to translate and adapt them to the understanding of domestic respondents in the banking sector.

The first part consists of 4 items related to knowledge creation based on the findings of Lee et al. (2005) and Mitchell and Boyle (2010). The second part includes 5 items related to knowledge sharing, adapted from Lee et al. (2005) and Liao et al. (2011). The third part of the questionnaire includes questions about an organizational culture that supports knowledge management, based on the questionnaire developed by the Gold et al. (2001). All items in the first three sections are of scalar type (five-level Likert scale). The fourth part of the questionnaire is aimed at collecting the general information about respondents, such as gender, age, position in the company and level of education, based on a closed type question.

Data processing was done using appropriate methods and techniques within the framework of the SPSS Package 20.0. The reliability of the scales Knowledge creation, Knowledge sharing and Knowledge culture was analyzed using Cronbach's alpha coefficient. Each of them has a high level of reliability ( $\alpha 1=0.887$ ( 4 items), $\alpha 2=0.758$ ( 5 items), $\alpha 3=0.777$ ( 7 items)).

For the purpose of testing the degree of knowledge creation and sharing in the Serbian banking sector, we calculated measures of descriptive statistics, arithmetic mean and standard deviation. Table 2 shows the results related to the knowledge creation. All the means are at the medium level (between 3 and 4), and the statement where the highest agreement is shown by the respondents is KC2 (Mean $=3.60$ ). This result is in line with previous research, which shows the importance of continuous training and development of bank employees (Stojanović-Aleksić et al., 2016, p. 46), since adequate training affects employee satisfaction, and consequently organizational performance (Jones et al., 2009, p. 170). Nevertheless, there is a space for improvement in this respect, too. On the other hand, knowledge creation from external sources, specifically external associates or experts outside the bank, is insufficiently developed.

Table 2 Knowledge Creation in the Serbian Banking Sector

\begin{tabular}{|c|c|c|c|c|c|}
\hline No. Item & $\mathrm{N}$ & Min. & Max & Mean & SD \\
\hline $\begin{array}{l}\mathrm{KC} 1 \text { In our bank, initiatives and activities undertaken towards } \\
\text { the generation of new ideas are valued. }\end{array}$ & 40 & 1 & 5 & 3.28 & 1.377 \\
\hline $\begin{array}{l}\text { KC2 My predecessor adequately introduced me to my tasks, } \\
\text { through educational programs for employees. }\end{array}$ & 40 & 2 & 5 & 3.60 & 0.955 \\
\hline $\begin{array}{l}\mathrm{KC} 3 \text { Employees are encouraged to search information for tasks } \\
\text { from various knowledge sources, eg. external experts }\end{array}$ & 40 & 1 & 5 & 3.10 & 1.105 \\
\hline $\begin{array}{l}\mathrm{KC} 4 \text { Employees actively promote the existing knowledge } \\
\text { through new ideas. }\end{array}$ & 40 & 2 & 5 & 3.35 & 0.921 \\
\hline
\end{tabular}

Source: Authors

Table 3 presents results related to knowledge sharing. The item KS6 has the highest mean (4.18), which indicates the consciousness of the link between knowledge sharing and organizational performance. Namely, employees in banks firmly believe that knowledge 
sharing increases the efficiency of the tasks. However, the perception about the existence of a reward system for knowledge sharing is significantly less developed (Mean $=2.75$ ). Thus, we can notice that employees in banks share knowledge primarily on the basis of personal initiative and on an ad-hoc basis, rather than as a result of the designed managerial approach. This segment should be improved, starting from the managerial level.

Table 3 Knowledge Sharing in the Serbian Banking Sector

\begin{tabular}{llccccc}
\hline No. & Item & $\mathrm{N}$ & Min & Max & Mean & SD \\
\hline KS5 & $\begin{array}{l}\text { My colleagues and I share the information and } \\
\text { knowledge needed to carry out our tasks. }\end{array}$ & 40 & 2 & 5 & 4.08 & 0.694 \\
KS6 & $\begin{array}{l}\text { We improve task efficiency by sharing information and } \\
\text { knowledge. }\end{array}$ & 40 & 3 & 5 & 4.18 & 0.675 \\
KS7 & $\begin{array}{l}\text { In our bank, there are developed information systems, } \\
\text { such as intranets or electronic bulletin boards, for } \\
\text { sharing information and knowledge. }\end{array}$ & 40 & 2 & 5 & 3.80 & 0.939 \\
KS8 & $\begin{array}{l}\text { We promote the sharing of information and knowledge } \\
\text { with other teams in the bank. }\end{array}$ & 40 & 2 & 5 & 3.82 & 0.984 \\
KS9 $\begin{array}{l}\text { In our bank, there is a system for rewarding knowledge } \\
\text { sharing. }\end{array}$ & 40 & 1 & 5 & 2.75 & 1.032 \\
\hline
\end{tabular}
Source: Authors

We applied the Mann Whitney U Test (Table 4) to compare statistically significant differences between two independent groups (employees and managers). This nonparametric test is applied because the variables do not follow the normal distribution, and the sample is big enough in relation to the entire population. The test is significant if the value of the indicator $p$ is less than or equal to 0.05. Based on the test results, the following conclusions can be drawn:

- there are statistically significant differences $(p<0,05)$ in the level of knowledge creation and sharing between employees and managers;

- the statistically significant differences are present in all individual items within the Knowledge Creation scale;

- the statistically significant differences are identified in items marked as KS7 and KS8 within the Knowledge Sharing scale.

Table 4 Differences in knowledge creation and sharing depending on the hierarchical level

\begin{tabular}{|c|c|c|c|c|c|c|}
\hline Item & $\begin{array}{l}\text { Knowledge } \\
\text { Creation }\end{array}$ & $\mathrm{KC} 1$ & $\mathrm{KC} 2$ & KC3 & $\mathrm{KC4}$ & KC5 \\
\hline Mann-Whitney $U$ & 58.0 & 69.0 & 81.0 & 54.0 & 87.0 & 127.00 \\
\hline Wilcoxon $W$ & 163.0 & 174.0 & 186.0 & 159.0 & 192.0 & 232.00 \\
\hline Z & -3.538 & -3.288 & -3.026 & -3.760 & -2.846 & -1.781 \\
\hline $\mathrm{p}$ & $0.000 *$ & $0.001 *$ & $0.002 *$ & $0.000 *$ & $0.004 *$ & 0.075 \\
\hline Item & $\begin{array}{c}\text { Knowledge } \\
\text { Sharing }\end{array}$ & KS6 & KS7 & KS8 & KS9 & \\
\hline$\overline{\text { Mann-Whitney } U}$ & 71.00 & 113.00 & 97.00 & 91.500 & 130.500 & \\
\hline Wilcoxon $W$ & 176,00 & 218.00 & 202.00 & 196.500 & 235.500 & \\
\hline $\mathrm{Z}$ & -3.187 & -2.163 & -2.577 & -2.747 & -1.562 & \\
\hline $\mathrm{p}$ & $0.001 *$ & 0.031 & $0.010 *$ & $0.006^{*}$ & 0.118 & \\
\hline
\end{tabular}


After we identified the statements in which there are statistically significant differences, it was necessary to determine which category of respondents expressed a higher level of agreement with them. Therefore, the medians were calculated and the results are shown in the Table 5. It can be noted that all the results are higher when respondents are managers. When it comes to knowledge creation, the differences are bigger in $\mathrm{KC} 1$ and $\mathrm{KC} 3$, and somewhat lower in $\mathrm{KC} 2$ and $\mathrm{KC} 4$. Thus, it can be concluded that managers in banks consider that their creativity and innovation are valued, while employees considerably less agree with this statement. In addition, bank managers believe that employees are encouraged to connect with experts outside the organization, while the employees much less agree with it. When it comes to the knowledge sharing, there is also a greater agreement with the statements shown by managers, although the differences are not so pronounced.

Table 5 Comparison of the knowledge creation and sharing between employees and managers

\begin{tabular}{lcccc}
\hline & \multicolumn{3}{c}{ Hierarchial level } \\
\cline { 2 - 5 } & \multicolumn{3}{c}{ Employee } & Manager \\
\cline { 2 - 5 } & $\mathrm{N}$ & Median & $\mathrm{N}$ & Median \\
\hline $\begin{array}{l}\text { KC1 - In our bank, initiatives and activities undertaken } \\
\text { towards the generation of new ideas are valued. }\end{array}$ & 14 & 2.00 & 26 & 4.00 \\
$\begin{array}{l}\text { KC2 - My predecessor adequately introduced me to my tasks, } \\
\text { through educational programs for employees. }\end{array}$ & 14 & 3.00 & 26 & 4.00 \\
$\begin{array}{l}\text { KC3 - Employees are encouraged to search information for } \\
\text { tasks from various knowledge sources, eg. external experts }\end{array}$ & 14 & 2.00 & 26 & 4.00 \\
$\begin{array}{l}\text { KC4 - Employees actively promote the existing knowledge } \\
\text { through new ideas. }\end{array}$ & 14 & 3.00 & 26 & 4.00 \\
$\begin{array}{l}\text { Knowledge creation - total } \\
\text { KS7 - In our bank, there are developed information systems, } \\
\text { such as intranets or electronic bulletin boards, for sharing } \\
\text { information and knowledge. }\end{array}$ & 14 & 3.00 & 26 & 4.00 \\
$\begin{array}{l}\text { KS8 - We promote the sharing of information and knowledge } \\
\text { with other teams in the bank. }\end{array}$ & 14 & 3.00 & 26 & 4.00 \\
Knowledge sharing - total & & & & \\
\hline
\end{tabular}

Source: Authors

Based on the data presented in Table 5, it can be concluded that this result is consistent with the attitude that knowledge management in banks is considerably more developed at higher hierarchical levels than in the lower ones.

\section{KNOWLEDGE-SUPPORTING CULTURE IN SERBIAN BANKING SECTOR: RESULTS OF THE RESEARCH}

The previous literature review leads to a conclusion that the organizational culture of enterprises is an important factor in the development of the knowledge creation and knowledge sharing. Namely, it is necessary to develop such a culture, which encompasses components (e.g. values, beliefs, norms, symbols) that support the concept of knowledge 
management. Therefore, for the purposes of this research, we applied the scale, composed of 7 items, which relate to the characteristics of the knowledge culture, and the results are shown in Table 6.

Table 6 Organizational culture that supports knowledge management

\begin{tabular}{|c|c|c|c|c|c|c|}
\hline No. & Item & $\mathrm{N}$ & Min & $\operatorname{Max}$ & Mean & SD \\
\hline$\overline{\mathrm{C} 10}$ & My colleagues are very approachable. & 40 & 2 & 5 & 3.78 & 1.050 \\
\hline $\mathrm{C} 11$ & $\begin{array}{l}\text { Employees understand the importance of } \\
\text { knowledge for the success of a bank. }\end{array}$ & 40 & 2 & 5 & 4.25 & 0.870 \\
\hline C12 & $\begin{array}{l}\text { Employees are encouraged to explore and } \\
\text { experiment. }\end{array}$ & 40 & 1 & 5 & 3.12 & 0.966 \\
\hline C13 & $\begin{array}{l}\text { Employees are valued on the basis of their } \\
\text { knowledge and expertise. }\end{array}$ & 40 & 1 & 5 & 3.15 & 1.272 \\
\hline C14 & $\begin{array}{l}\text { Employees are encouraged to seek help from } \\
\text { others when they need it. }\end{array}$ & 40 & 2 & 5 & 3.48 & 0.784 \\
\hline C15 & $\begin{array}{l}\text { Employees are encouraged to discuss the } \\
\text { business with colleagues. }\end{array}$ & 40 & 2 & 5 & 3.15 & 0.921 \\
\hline $\mathrm{C} 16$ & $\begin{array}{l}\text { Senior management set clear vision and } \\
\text { emphasized the importance of knowledge for } \\
\text { the success of our bank. }\end{array}$ & 40 & 2 & 5 & 3.63 & 0.868 \\
\hline
\end{tabular}

Source: Authors

The results show that the knowledge culture in the banking sector is at the medium level, and that there are differences in the development of certain components of this culture. Namely, the best estimated item is: "Employees understand the importance of knowledge knowledge for the success of a bank" (Mean = 4.25), which is a good prerequisite for knowledge creation in banking sector. However, there is a significantly lower average for the following items: $\mathrm{C} 12$ (Mean = 3.12); $\mathrm{C} 13$ (Mean = 3.15) and C15 (Mean $=3.15)$. It can therefore be assumed that employees, although having a relatively developed awareness of the importance of knowledge and good communication to colleagues, are not motivated or encouraged enough to manage knowledge.

\section{CONCLUSION}

Knowledge is the most important and unique source of sustainable competitive advantage in the era of knowledge economy (Nonaka \& Takeuchi, 1995). Knowledge creation and knowledge sharing influence the improvement of the service quality, shortening the time needed to perform tasks, creating the conditions for developing new ideas, which increases both the effectiveness and efficiency of the bank. Bearing in mind the significance of these processes, the paper focuses on identifying the level of knowledge creation and sharing in the Serbian banking sector, with a special emphasis on the differences in the level of development of these processes between managers and employees. In addition, as a relevant knowledge management factor, the degree of development of an organizational culture that supports knowledge is examined.

The findings of an empirical study indicate the medium level of the knowledge creation. Banking management devotes a lot of attention to the development of 
knowledge through the programs of training and professional development. Also, it can be noted that the employees strive to actively improve their competencies. It is necessary to continue with this practice and to further develop it, in order to make the advancement from a very good to the excellent level. On the other hand, less knowledge is created through networking or connecting with external sources of knowledge, such as, for example, external associates. Encouraging employees to connect with experts outside the organization is one of the challenges that management needs to face in the future period.

When it comes to knowledge sharing, there is a high level of deviation of the individual statements' scores from the overall average score. Namely, the respondents assessed better the degree of knowledge sharing and the benefits of sharing information with colleagues, while the results are lower for the ICT support for knowledge sharing. The results are the lowest when it comes to the system for rewarding knowledge sharing.

Both knowledge creation and sharing are more developed at the managerial level. However, it is not possible to make at a general conclusion about the cause of such a gap between the hierarchical levels, so it would be interesting to further analyze the factors that lead to these differences in future research. It can only be assumed that the reasons are diverse, linked to individual factors, such as, for example, personal characteristics, level of education or organizational factors - leadership style, motivation system, communication and more. Still, it is possible to refer certain recommendations and guidelines to the banking management in Serbia in terms of encouraging the knowledge creation and sharing at lower levels. Although creativity and innovativeness of all employees is not essential in carrying out banking activities, it is very important to take into account the opinions and ideas of employees regarding how to perform tasks, relationship with clients, communication with colleagues and many other issues. If management shows interest in suggestions and ideas of employees and allows them to participate in decision-making regarding their work, i.e. if the level of vertical specialization is reduced at lower hierarchical levels, the process of knowledge creation can be improved. Additionally, although managers are in charge of establishing cooperation with external parties, they should also motivate employees to participate in such forms of cooperation through an active support and exchange of contacts, in order to enrich the knowledge not only from internal but also from external sources.

One of the essential incentive factors for knowledge creation and sharing is an organizational culture that supports knowledge. The results of the survey show that certain elements of organizational culture create a good base for the knowledge management in Serbian banking sector. Those elements are the awareness of the importance of knowledge both for employees and management and good communication with colleagues, but there is still a potential for the further improvement and development. In this respect, the roles of leaders in banks are significant. They should encourage and motivate employees in the right way to acquire, share and apply knowledge. It is very important to develop an environment in which there are equal conditions for everyone and where people are valued on the basis of their knowledge and expertise. Leaders and managers should evaluate and value both tacit and explicit components of employees' knowledge. Future consideration on the employee performance evaluation should be focused on incorporating intangible intellectual capital factors, in addition to the hard, quantitative indicators.

Knowledge management has not been explored enough in the banking sector, and especially not in Serbia. The findings in this paper provide a significant contribution to 
the literature, both in the fields of banking management and knowledge management. We highlight the importance of the problem area and point to a number of issues and problems that need to be further explored in order to properly manage the knowledge as a resource in banks. On the other hand, the practical implications of research are reflected in providing information to the bank managers in Serbia about the level of development of the knowledge creation, knowledge sharing and knowledge culture. It is possible to identify the specific elements of the observed processes and culture, which are at a high, medium and low level, and accordingly direct future efforts to improve the knowledge management, with the aim of improving the quality of providing banking services and achieving a sustainable competitive advantage.

In addition to significant contributions, there are certain limitations. First of all, the empirical study shows the level of knowledge creation, knowledge sharing and knowledge culture in Serbian banking sector, but the factors that affect them are not explored. Therefore, future research should consolidate the findings through the investigation of different individual, organizational and technological factors of knowledge management in banks. The second limitation stems from the known shortcomings of the survey, as data collection techniques, and above all from the subjectivity of the respondents and the impossibility of reaching more extensive responses and better observations. The sample accounts for about $37 \%$ of the total number of banks in Serbia, which is a relatively large sample, but there is still a probability of making mistakes, as well as the possibility of expanding the database of respondents in the future. Fourthly, the research was carried out at a single point of time, which makes it difficult to monitor the dynamics of the knowledge management process.

Despite the limitations, the paper is a good basis for future research, as it points to a number of relevant research questions, such as: whether and how the knowledge creation and sharing in the banking sector affect the degree of knowledge application, why there are differences in the knowledge creation and sharing between the hierarchical levels, what is the extent of the influence of knowledge culture on the knowledge management in banks, what are the other factors that determine the level of knowledge management in banks, etc. These and many other issues once again point to the importance of the topic and motivate researchers to continue looking for answers and providing guidance to managers in solving everyday problems in a modern business environment.

Acknowledgement: The paper is a part of the research done within the projects no. 41010 and no. 179062. The authors would like to thank to the Ministry of Education, Science and Technological Development of the Republic of Serbia.

\section{REFERENCES}

Aleksić-Mirić, A. (2017). Trendovi u poslovnom okruženju i njihov uticaj na dizajn organizacije [Business Environment Trends and Its Impact on Organizational Design]. In: Janićijević, N., Grubor, A., Končar, J. \& G. Petković (editors), Management and Marketing - Trends and Effects on Serbian Market Efficiency, Belgrde: Faculty of Economics, 65-78

Al-Abdullat, B. M. \& Dababneh, A. (2018). The mediating effect of job satisfaction on the relationship between organizational culture and knowledge management in Jordanian banking sector. Benchmarking: An International Journal, 25 (2), 517-544. doi:10.1108/BIJ-06-2016-0081. 
Association of Serbian Banks (2016). Serbian Banking Sector - Analysis of financial position and finansial performace, Avaliable at: http://www.ubs-asb.com/LinkClick.aspx?fileticket=Gwgn93a7nJE\%3d\&tabid=538\&mid=20666.

Curado, C. (2008). Perceptions of knowledge management and intellectual capital in the banking industry. Journal of Knowledge Management, 12 (3), 141-155. https://doi.org/10.1108/13673270810875921.

Davies, F., Moutinho, L. \& Curry, B. (1995). Construction and testing of a knowledge-based system in retail bank marketing. International Journal of Bank Marketing, 13 (2), 4-14. https://doi.org/10.1108/02652329510078613.

Della Peruta, M., Campanella, F. \& Del Giudice, M. (2014). Knowledge sharing and exchange of information within bank and firm networks: the role of the intangibles on the access to credit. Journal of Knowledge Management, 18 (5), 1036-1051. https://doi.org/10.1108/JKM-06-2014-0255.

Dugalić, V. (2016). Kako se pripremiti za budućnost? - Uvodnik [How to prepare yourself for future? Editorial]. Bankarstvo, 45 (4), 6-19.

Gold, A.H., Malhotra, A. \& Segars, A.H. (2001). Knowledge management: an organizational capabilities perspective. Journal of Management Information Systems, 18 (1), 185-214. https://doi.org/10.1080/07421222.2001.11045669.

Gupta, A.K. \& Govindarajan, V. (2000). Knowledge management social dimension: lessons from Nucor Steel. Sloan Management Review, 42 (1), 71-81.

Hutchinson, J. \& Xavier, A. (2006). Comparing the impact of credit constraints on the growth of SMEs in a transition country with an established market economy, Small Business Economics, 27 (2-3), 169-179. DOI 10.1007/s11187-005-4412-3.

Islam, M.Z., Jasimuddin, S, M. \& Hasan, I. (2015). Organizational culture, structure, technology infrastructure and knowledge sharing. VINE Journal of Information and Knowledge Management Systems, 45 (1), 67-88. https://doi.org/10.1108/VINE-05-2014-0037.

Jayasundara, C. (2008). Knowledge Management in Banking Industries: Uses and Opportunities. Journal of the University Librarians Association of Sri Lanka, 12, 68-84. http://doi.org/10.4038/jula.v12i0.329.

Jones, M. K., Jones, R. J., Latreille, P. L. \& Sloane, P. J. (2009). Training, Job Satisfaction, and Workplace Performance in Britain: Evidence from WERS 2004. LABOUR, 23, 139-175. IZA Discussion Paper No. 3677. Retrieved from: SSRN: http://ssrn.com/abstract=1264552 or http://dx.doi.org/10.1111/j.0042-7092.2007.00700.x 10.02.2016.

Lee, K. C., Lee, S. \& Kang, I. W. (2005). KMPI: measuring knowledge management performance. Information \& Management, 42 (3), 469-482. https://doi.org/10.1016/j.im.2004.02.003.

Liao, C., Chuang, S.H. \& To, P.L. (2011). How KM mediates the relationship between environment and organizational structure. Journal of Business Research, 64 (7), 728-736. https://doi.org/10.1016/j.jbusres.2010.08.001.

Ma, Z., Huang, Y.,Wu, J., Dong, W. \& Qi, L. (2014). What matters for knowledge sharing in collectivistic cultures? Empirical evidence from China. Journal of Knowledge Management, 18 (5), 1004-1019. http://dx.doi.org/10.1108/JKM-06-2014-0252.

Mahmoudsalehi, M., Moradkhannejad, R. \& Safari, K. (2012). How knowledge management is affected by organizational structure. The Learning Organization, 19 (6), 518-528. https://doi.org/10.1108/ 09696471211266974

Mirzaee, S. \& Ghaffari, A. (2018). Investigating the impact of information systems on knowledge sharing. Journal of Knowledge Management, 22 (3), 501-520. https://doi.org/10.1108/JKM-08-2017-0371.

Mitchell, R. \& Boyle, B. (2010). Knowledge creation measurement methods. Journal of Knowledge Management, 14 (1), 67-82. https://doi.org/10.1108/13673271011015570.

National Bank of Serbia. www.nbs.rs, 20.01.2018.

Nonaka, I. (1994). A Dynamic Theory of Organizational Knowledge Creation. Organization Science, 5 (1), 14-37.

Nonaka, I. \& Takeuchi, H. (1995). The Knowledge-Creating Company: How Japanese Companies Create the Dynamics of Innovation, Oxford: Oxford University Press.

Nonaka, I., Toyama, R. \& Konno, N. (2000). SECI, Ba and leadership: a unified model of dynamic knowledge creation. Long Range Planning, 33 (1), 5-34. https://doi.org/10.1016/S0024-6301(99)00115-6.

Pauleen, D. J. \& Wang, W.Y.C. (2017). Does big data mean big knowledge? KM perspectives on big data andanalytics. Journal of Knowledge Management, 21 (1), 1-6, https://doi.org/10.1108/JKM-08-2016-0339.

Slavković, M. (2013). Strategijsko upravljanje ljudskim resursima u ekonomiji zasnovanoj na znanju [Strategic human resources management in knowledge-based economics]. Ph.D. Thesis. Faculty of Economics University of Kragujevac.

Stojanović-Aleksić, V., Erić Nielsen, J. \& Bošković, A. (2016). Social Responsibility in the Banking Sector: Experience from Serbia. Bankarstvo, 45 (2), 35-55. doi: 10.5937/bankarstvo1602034S. 


\section{UPRAVLJANJE ZNANJEM U BANKARSKOM SEKTORU REPUBLIKE SRBIJE}

Suočavanje sa savremenim izazovima u bankarskom sektoru, vezanim za hiperkonkurenciju $i$ sve teže tržišno diferenciranje, kao $i$ održavanje $i$ unapređenje poslovnih rezultata, zahteva podršku odgovarajućeg sistema upravljanja znanjem. Upravljanje znanjem uključuje više faza, a u radu je poseban akcenat stavljen na kreiranje i deljenje znanja. Pored toga, rad pruža kratak uvid $u$ karakteristike organizacione kulture koja podržava upravljanje znanjem. Osnovni ciljevi istraživanja jesu da se utvrde nivoi razvijenosti kreiranja znanja, deljenja znanja i organizacione kulture koja podržava znanje u bankarskom sektoru u Srbiji. Pored pregleda literature, sprovedena je anketa, nakon čega su podaci obrađeni statističkim metodom. Rad pruža doprinos literaturi, kako iz oblasti bankarskog menadžmenta, tako i upravljanja znanjem. Saznanja do kojih se dolazi mogu biti korisna i menadžerima banaka, jer se osvetljava značaj upravljanja znanjem u bankama i ukazuje na razvijene, manje razvijene $i$ nedovoljno razvijene aspekte procesa kreiranja $i$ deljenja znanja, pružajući praktične smernice za unapređenje istih.

Ključne reči: upravljanje znanjem, kreiranje znanja, deljenje znanja, bankarski menadžment 